\title{
Ruslands identitet og forhold til Vesten
}

Flemming Splidsboel Hansen Forskningskoordinator, ph.d., Forsvarsakademiet

Efter en vanskelig søgen efter en ny postsovjetisk identitet synes en stor del af den russiske befolkning nu at have fundet "tilbage" til en identitet, som i en vis udstrækning hviler på dyb mistro til Vesten. Denne proces er blevet anført af ledende politikere i landet, og den er blevet vel modtaget af en befolkning, som har været usikre på, hvilken fælles identitet de egentlig har. For Vesten er der en stor udfordring $i$ at få vendt denne udvikling og få den russiske befolkning til at føle sig tryg ved en identitet, som er baseret på et værdifællesskab med Vesten.

Den måske mest bemærkelsesværdige udvikling i Rusland i 2000'erne var landets stadig mere selvsikre adfærd internationalt. Dette gjaldt i særdeleshed forholdet til Vesten, som i stigende grad blev karakteriseret ved konfrontation og en åben afvisning af mange af de værdier og normer, som Vesten i årene efter den kolde krig har forsøgt at udbrede til ikkedemokratiske styrer.

Denne udvikling blev ledsaget af en intern proces, som var dels konsekvens af dels årsag til det forværrede forhold til Vesten. På den ene side skabte ledende politikere en fortælling om et Vesten, som betragter Rusland med mistro og ikke ønsker, at landet rejser sig igen. På den anden side forsøgte de samme politikere at fjerne landet stadig mere fra Vesten ved at formulere en ny russisk identitet, som hviler på såkaldte ægte russiske værdier og normer. De to elementer i denne proces er gradvis blevet accepteret af en stor del af den russiske befolkning, og de har kunnet forstærke hinanden i en nedadgånde spiral, som har bragt os til et punkt, hvor der endog er blevet advaret om risikoen for en ny kold krig.
Denne risiko synes dog minimal. Men der synes at være skabt en negativ interaktion, som blot vanskeligt kan brydes. Et særligt aspekt af denne interaktion er omformuleringen af en ny „semiofficiel“ identitet og dennes forhold til Vesten. Som nævnt har den nye identitet bidraget til den nedadgående spiral, men den har samtidig givet den brede russiske befolkning en klarere forståelse af, „hvem de er", og på den måde har den styrket deres såkaldte ontologiske sikkerhed. Udfordringen for Vesten består i at få denne del af den russiske befolkning til at udvikle og internalisere en provestlig identitet, uden at de derved mister deres klare følelse af eksistens.

\section{Ontologisk sikkerhed}

Ontologi er læren om det værende eller, som en lærebog i videnskabsteori beskriver det, „that bit of philosophy which studies what sorts of things exist" (Bird 2002: 296 n16). Begrebet har således at gøre med eksistens. Det har primært været benyttet inden for psykologi og udviklingslære, og her betegner det individets forhold til selvet, dvs. individets forhold til sin egen „,indre kerne“ eller følelse af væren. Ontologisk sikkerhed er på den måde sikkerhed for selvet.

Ideen om ontologisk sikkerhed hviler stadig i høj grad på den skotske psykiater Ronald David Laings pionerarbejde i 1960'erne (fx Laing 2006). Laing understregede nødvendigheden af også at fokusere på det eksterne miljø og på forskellige aktørers indbyrdes forhold for helt at forstå kompleksiteten af de psykiske lidelser, deriblandt de som er forårsaget af manglende ontologisk sikkerhed.

For det enkelte individ grundlægges den stærke følelse af væren i de tidlige leveår, især via barnets primære omsorgspersoner. Derefter vedligeholdes den i et konstant samspil med omgivelserne, og via dagligdagens bekræf- 
telse af vaner, rutiner og gensidige roller skabes et stabilt og forudsigeligt miljø, hvor individet kan føle sig sikker på sig selv og sin egen identitet. Men hvis de primære omsorgspersoner svigter deres opgave, kan den ontologiske sikkerhed blot meget vanskeligt, hvis overhovedet, opbygges senere i livet. Den engelske sociolog Anthony Giddens (1991: 39) forklarer, at

\begin{abstract}
„The very young child is not a 'being', but a 'goingon being', who has to be 'called into existence' by the nurturing environment which the caretaker provides. The discipline of routine helps to constitute a 'formed framework' for existence by cultivating a sense of 'being', and its separation from 'non-being', which is elemental to ontological security".
\end{abstract}

Laing så det som et grundlæggende menneskeligt behov at have en stærk følelse af væren, og han betragtede det som en forudsætning for, at individet kan udvikle en sund og stabil psyke. Ifølge Laing (2006: 42) vil en sådan person

„... experience his own being as real, alive, whole; as differentiated from the rest of the world in ordinary circumstances so clearly that his identity and autonomy are never in question; as a continuum in time; as having an inner consistency, substantiality, genuineness, and worth; as spatially co-extensive with the body; and, usually, as having begun in or around birth and liable to extinction with death. He thus has a firm core of ontological security“.

Således er det dog naturligvis - og desværre - langt fra altid. En ontologisk usikker person kan således have vanskeligt ved at finde et mønster i sin egen og andres roller og ved at se den temporale kontinuitet i sit eget liv; det fremstår ikke som et ubrudt forløb men i stedet som en serie af separate episoder uden en rød tråd (Laing 2006: 43). Det er afgørende for fastholdelsen af selvet, som den canadiske filosof Charles Taylor udtrykker det, at individet kan bevare en ubrudt fortælling om sin egen person; vi ved kun, hvem „vi“ er, hvis vi samtidig forstår, hvor „,vi“ kommer fra, og hvor „vi“ er på vej hen (Taylor 1989: 47).

Sikkerhedsteoretikeren Bill McSweeney trækker i sit arbejde på psykologiske eksperimenter, hvor man bevidst nedbryder ellers tillidsfulde forhold, og på den baggrund sammenligner han mangelen på ontologisk sikkerhed med den den følelse, som ofrene for skjult kamera har (McSweeney 1999: 155). Her møder aktøren en tilsyneladende bekendt og tryg situation, som hun under normale omstændigheder ville være fuldt fortrolig med. Således behersker hun den rolle, hun selv skal indtage, ligesom hun har klare forventninger til de andre aktørers roller. I stedet udsættes hun for et tillidsbrud, hvor de andre aktører ikke spiller de forventede roller, og hvor hun derfor også selv kastes ud i en ny og ukendt rolle. Det er forvirringen og den akutte stress i den uventede og utrygge situation, som skjult kamera er bygget på; og det er det, som gør situationen ubehagelig for ofret.

Disse tanker om ontologisk sikkerhed for individet er i de senere år blevet løftet op, så det nu i stigende grad bliver anvendt på grupper af individer, $\mathrm{fx}$ nationer. Disse fællesskaber tillægges altså nu det samme grundlæggende behov for at føle sig sikre i deres egne respektive identiteter, som også individet gør (fx Mitzen 2006 og Steele 2005 og 2008). Fra egne foredrag har jeg erfaret, hvor kontroversielt dette er for mange mennesker. De modsætter sig ganske enkelt ideen om, at man så enkelt kan gøre individets psykiske behov til fællesskabets.

Lad mig derfor understrege, at når den ontologiske sikkerhed på denne måde løftes op på det kollektive niveau, ligger der ikke i dette, at den erstatter behovet for ontologisk sikkerhed på andre niveauer; som mennesker har vi mere end blot én kilde til selvidentifikation. Der ligger heller ikke i det, at den ontologiske sikkerhed på det kollektive niveau nødvendigvis tillægges samme status som på det individuelle niveau. Den kollektive identitet i fx nationen er blot én i rækken af identiteter, hvoraf flere er kollektive, men hvor de vigtigste ofte er de nære og individuelle.

Derudover skal det erindres, at vi ofte og egentlig ganske selvfølgeligt overfører tilsvarende menneskelige behov til andre analyseobjekter som $\mathrm{fx}$ staten. Således bygger $f_{x}$ megen teori på en grundlæggende antagelse om, at staten ønsker at „overleve“, på samme måde som de fleste sunde og velfungerende mennesker også gør; det er en solid antagelse, idet staternes „selvmordsrate“ er yderst lav. Men det er også en kontroversiel antagelse, idet den indebærer en antropomorfisering af et ikkemenneskeligt objekt (fx Mitzen 2006: 352).

I modsætning til individet, hvis følelse af væren grundlægges i de første år efter fødslen, dvs. ved starten af en tidsmæssigt meget velafgrænset periode, modtager fællesskabet løbende sin følelse af væren i arv fra tidligere generationer og deres konstruktion af „os“. Den forhandles kontinuerligt blandt fællesskabets medlemmer og i samspil med eksterne aktører. Men som for individet gælder også for fællesskabet, at den ontologiske sikkerhed vedligeholdes via en konstant interaktion med omgivelserne. 


\section{Den russiske forståelse af selvet}

Den russiske identitet har været udsat for dramatiske omfortolkninger i de seneste 25 år. De første store ændringer kom i årene umiddelbart efter 1985, da Mikhail Gorbatjov overtog posten som leder af det sovjetiske kommunistparti, men udviklingen tog yderligere fart efter Sovjetunionens sammenbrud. I et fuldstændigt brud med selv den allernærmeste fortid valgte den nye russiske ledelse under daværende præsident Boris Jeltsin at gøre Sovjetunionen til Ruslands konstituerende anden, dvs. den direkte modsætning, som giver en aktør form og indhold.

De russiske politikere udtrykte åbent deres ønske om at imitere Vesten og dermed indføre et liberalt demokrati, en fri markedsøkonomi og et tæt sikkerhedsfællesskab med de vestlige lande og organisationer, som blot få år forinden var blevet præsenteret som fjendebilleder for den sovjetiske befolkning (fx Tsygankov 2006: kapitel 3). Dette drastiske skridt skyldtes ikke alene, at det for Jeltsin og hans reformkolleger var det "rigtige“ at gøre; det ville også lette og fremskynde den fuldstændige afsovjetisering, som Jeltsin havde gjort til sit politiske hovedprojekt.

Rusland var i starten en af transitionsklassens mest lærevillige og ambitiøse elever: Omstillingen fra det autokratiske sovjetstyre og den økonomiske planlægning til et liberalt demokrati og en markedsøkonomi med minimal regulering skulle gennemføres så hurtigt som muligt. Jeltsin ville sikre sig, at der ikke var nogen vej tilbage til fortiden for den russiske befolkning, og for at opnå dette var han parat til at kaste sig selv og resten af landet ud på dybt vand.

I dag kan vi konstatere, at de første reformpolitikeres ideer ikke slog helt igennem. Det skyldtes for det første den meget uheldige men egentlig også ganske naturlige omstændighed, at de russiske vælgere forbandt den nye identitet med nogle af de mest negative følger af den nye politik. Omfattende magtmisbrug og korruption foruden et uhyrligt socialt kollaps blev set som elementer af den nye demokratiske, liberalistiske og vestlige identitet, som Kreml forsøgte at brede ud over landet. Og på den måde var Jeltsins store spring fremad hurtigt dødsdømt.

Men det skyldtes for det andet også det forhold, at mange i Rusland havde forventet at se flere imødekommelser fra Vestens side (fx Basjanov 2001: 216-225). Den officielle russiske fortælling var jo nu, at landet havde brudt fuldstændig med fortiden og var blevet som „os“ i Vesten. De respektive roller og det indbyrdes forhold skulle derfor ændres, så det afspejlede den nye virkelighed, men det skete ikke i det omfang og tempo, som russerne havde regnet med, og som deres egne ledere havde stillet dem i udsigt.
De blev ikke behandlet som et fuldgyldigt medlem af fællesskabet; der var stadigvæk en vis distance. Den fuldstændige omfavnelse kunne dog også blot vanskeligt forekomme. „De“ var jo tydeligvis ikke endnu som „os“, og vi hverken kunne eller skulle foregive, at forholdene i Rusland ikke afveg fra vores standarder, når de nu faktisk gjorde det. Om noget var vi måske ikke tilstrækkeligt kritiske, fordi vi frygtede, at befolkningen stadigvæk kunne huske vejen tilbage til sovjetsystemet, og at det derfor var bedre at fremhæve succeserne snarere end at kritisere manglerne (fx Dobriansky 1999: 138-139).

Men i den russiske skuffelse ligger efter min opfattelse en nøgle til at forstå grundlaget for den uheldige udvikling i forholdet mellem Rusland og Vesten, som vi har været vidner til de seneste 10-15 år. Den amerikanske forsker Robert Jervis (1976: 66) beskrev det ganske fint $i$ en helt anden sammenhæng, da han forklarede, at det centrale tema „ikke er ondskab men tragedie“. Der har, som også anført nedenfor, været en del ondskab i form af politisk manipulation, men det primære synes at have været misforståelser og uindfriede forventninger. Det er vigtigt, at vi forsøger at forstå, præcis hvilken skade dette har gjort, så vi kan undgå lignende udviklinger i fremtiden.

Den russiske opfattelse af Vestens rolle i dette kommer særdeles tydeligt og repræsentativt til udtryk i en ny bog af den russiske forsker Veronika Krasheninnikova. Det er en studie i russisk skuffelse; den gennemgår en lang række aspekter af især det amerikanske syn på Rusland, og Krasheninnikova påpeger, hvad hun ser som en næsten systematisk fejltolkning af de russiske forhold. Hvordan kan det være, spørger hun, at russerne stort set aldrig kan genkende deres eget land i de beskrivelser, som de læser og hører om fra Vesten (Krasheninnikova 2007: 20)? En del af svaret, ifølge hende selv, skal findes i almindelige forståelsesmæssige forhold: Velbeskrevede kognitive begrænsninger, som $\mathrm{fx} g \varnothing r$, at man blot vanskeligt kan se en anden aktørs overgang fra en tidligere til en nuværende identitet; at dissonant information forkastes, fordi det ikke passer ind i allerede eksisterende paradigmer; og at det enkelte menneske har en tendens til stædigt at fastholde allerede eksisterende billeder af såvel sig selv som af andre (Krasheninnikova 2007; også Heuer 1999).

I denne artikels sammenhæng har det, igen ifølge Krasheninnikova, betydet, at Vesten har holdt fast i et syn på Rusland, som egentlig er mere sovjetisk, end det er aktuelt; at Vesten hæfter sig ved de negative aspekter af udviklingen i Rusland, som svarer til vores allerede etablerede forestillinger om landet, mens vi mere eller mindre bevidst afviser eller nedtoner ellers positive udviklingstræk; og at Vesten ser sig selv som „den gode“ og 
giver sig selv ret i enhver konflikt med andre, deriblandt Rusland (Krasheninnikova 2007).

Jeg kan tilføje, at jeg selv i flere tidligere arbejder ( $\mathrm{fx}$ Hansen 2002b) har forsøgt at illustrere, hvor anderledes genstandsfeltet „russisk udenrigspolitik“ kan tage sig ud, når det analyseres ud fra forskellige paradigmer inden for International Politik. Det betyder ikke, at alt kan reduceres til en postmoderne "historiefortælling" ( $\mathrm{f}_{\mathrm{x}}$ Southgate 1996: kapitel 6), hvor alt har lige værdi og relevans, men blot at man som aktør bestræber sig på at være så mange af sine strukturelle begrænsinger bevidst som muligt.

Det skal dog samtidig erindres, at det indtryk, som den enkelte aktør tror, hun giver til sine omgivelser, ikke nødvendigvis er det samme indtryk, som omgivelserne rent faktisk far af hende (Ichheiser 1949 og Goffman 1958). Der vil ofte være en betydelig uoverensstemmelse mellem de to, således som der givetvis også har været - og er - en uoverensstemmelse mellem Ruslands billede af sig selv og så Vestens billede af Rusland. Den manglende russiske selvindsigt kan i en vis udstrækning tilskrives kognitive begrænsninger af samme typer som beskrevet ovenfor; man kan simpelthen ikke opnå at se sig selv på samme måde, som andre ser en.

Det betyder dog ikke, at vi ikke har begået fejl. Øget opmærksomhed på dette følsomme emne kunne have fået os til i højere grad at acceptere, at Rusland fik lov at spille symbolske roller som medlem af et større fællesskab - det kunne fx være som „medvinder" af den kolde krig. Disse roller kunne vi så have bekræftet via vores handlinger, og på den måde kunne vi have bidraget til at skabe et eksternt miljø, som gik et skridt videre i retning af at understøtte den nye russiske identitet. I stedet skete der for ofte det, at mange russere, primært pga deres egne fejlagtige forventninger til de indbyrdes roller i deres forhold til Vesten, følte sig som ofre for McSweeneys skjulte kamera. De troede, de skulle indtage rollen som den nære slægtning, som efter mange års adskillelse bliver budt varmt velkommen tilbage af sin familie; i stedet, som de ser det, indtager de rollen som opgangens nye og fremmede beboer, som trods sine mange forsøg på at komme tættere på de andre lejere fortsat og konsekvent bliver betragtet med mistro.

\section{Ontologisk sikkerhed for Rusland}

Som nævnt gør manglende ontologisk sikkerhed det vanskeligt at etablere og fastholde et stabilt og forudsigeligt forhold mellem de involverede aktører. Den berømte amerikanske psykolog Carl Rogers fortæller fx i en af sine bøger om en kvindelig klient, som opsøgte ham pga. et svagt udviklet selv. Kvinden havde levet sit liv efter andres krav og forventninger, og hun forklarede Rogers (2004: 109), at

„I just didn't stand up for my own convictions, until I don't know whether I have any convictions to stand up for. I haven't been really honest being myself, or actually knowing what my real self is, and I've been just playing some sort of false role“.

Rogers forklarer selv, at klienterne gennem terapien ofte opdager, at de faktisk alene eksisterer i forhold til andres forventninger, at de ikke har deres eget selv, og at de kun forsøger at tænke, føle og agere på den måde, som andre synes, de skal tænke, føle og agere (Rogers 2004: 110).

Det kræver efter min opfattelse blot et overfladisk kendskab til russisk politik siden 1992 - og måske en anelse mere fantasi - at se Rogers' klient som en repræsentation af Rusland. Skiftende russiske præsidenter fra Jeltsin (1991-1999) over Vladimir Putin (1999-2008) til Dmitrij Medvedev (2008-) - har således tumlet med samme type af spørgsmål, som denne kvinde også gjorde: Hvilken type af stat er Rusland egentlig? Hvad er landets identitet? $\mathrm{Og}$, som en naturligvis forlængelse af svarene på disse to spørgsmål, hvad er Ruslands interesser?

I løbet af 1990'erne stod det stadig tydeligere klart, at Rusland ikke havde været helt ærlig over for hverken sig selv eller os. Rusland var ikke, hvad ledende russiske politikere i begyndelsen af tiåret ellers havde hævdet og foregivet, at det var. Det havde i stedet en anden identitet baseret på andre værdier og normer. Det russiske selv var ikke lig Vestens selv, og Ruslands interesser var derfor heller ikke lig Vestens interesser (Steele 2008: 34). Landet havde, som Rogers' klient, spillet en slags falsk rolle, og det var en rolle, som ikke fandt genklang i eller blev støttet af det rigtige russiske selv.

I denne falskhed ligger også en del af forklaringen på, at vi havde vanskeligt ved at anerkende den nye russiske identitet. Der var for meget „papegøjesnak“, dvs. en overfladisk retorik, som blot syntes at afspejle en simpel læringsproces og dermed en svag internalisering af de normer, som man nu ellers hævdede var styrende. Der var, udtrykt mere simpelt, for langt mellem retorikken og de bagvedliggende holdninger. Men som illustreret af eksemplerne fra Krasheninnikovas bog skal vi være opmærksomme på, at vi muligvis har bidraget til at skubbe mange russere væk fra dele af den nye identitet, som de ellers var klar til at acceptere som deres egne.

Det er for tidligt at afsige dom over Medvedevs embedsførelse, da vi endnu ikke kan se dens endelige aftryk på det russiske samfund. Men hvad angår de to tidligere præsidenter, kan det lidt fortegnet siges, at hvor Jeltsin i 
en revolutionær udvikling forsøgte at tvinge den russiske befolkning væk fra dens tidligere identitet, da har Putin bragt den et godt stykke tilbage igen. Under hans styre fandt den brede del af befolkningen tilbage til en del af dens selv, som den er fortrolig med, og som derfor giver den større tryghed end de voldsomme skift i 1990'erne. Efter min mening er det, uanset hvad man ellers måtte mene om den nye russiske identitet, en af Putins største bedrifter som præsident, og det er en af forklaringerne på, at han nyder så stor popularitet i landet. Han har, for nu at formulere det lidt populært, givet den russiske befolkning psykoterapi efter de traumatiske og identitetsforstyrrende oplevelser i 1990'erne.

På samme tid som de første reformpolitikere argumenterede for, at Rusland skulle imitere Vesten, da begyndte andre og konkurrerende meningsdannere at formulere en alternativ identitet, som i bund og grund blot var en negation af de samme værdier og normer. Alt hvad Vesten var, ja, det var Rusland ikke. Bl.a. blev vores individualisme, liberalisme og påståede konsumerisme således afvist med dommen „ikkerussiske værdier“" (selvom den gennemsnitlige russer faktisk fokuserer meget på forbrug).

Putin har siden taget denne proces et skridt videre. Han har stået i spidsen for en omformulering af de negative værdier, dvs. negationerne, til positive værdier. De „ægte“ russiske værdier er nu bl.a. kollektivisme, orden og spiritualitet (de to sidstnævnte som misforståede modsætninger til hhv. liberalisme og konsumerisme). Som uddybet nedenfor er denne udvikling, ganske naturligt, blevet ledsaget af en afvisning af Vestens påståede politiske missionering (fx Lusjkov 2007; Krasheninnikova 2006: 188). Rusland påberåber sig, retten til at indføre sit eget, russiske politiske system; i dette ligger en indbygget konflikt med Vesten, som man er overbevist om vil forsøge at forhindre Rusland $i$ at finde tilbage til sit eget mere oprindelige og ægte selv.

\section{Rusland og Vesten}

Bagtæppet for den russiske identitetsdannelse har været mistro til Vesten. Der var en ganske kort periode omkring Sovjetunionens sammenbrud, hvor denne mistro var vanskelig at få øje på, men den lå meget latent under overfladen og ventede på at finde et legitimt udtryk ( $f x$ Krasheninnikova 2006: 343). Den nye russiske stat var således blot få måneder gammel, da de russiske medier begyndte at berette om politikere og kommentatorer, som kort forinden havde beskrevet sig selv som provestlige, men som nu havde besluttet at konvertere tilbage til deres tidligere og velkendte udenrigspolitiske overbevisninger. Fx advarede en artikel i begyndelsen af 1992 om, at de russiske meningsdannere var ved at forberede offentlighe- den på en kommende konflikt med Vesten. Baggrunden var den påståede russiske defaitisme og Vestens ydmygelse og svigt af landet (Razuvajev 1992).

Netop den påståede ydmygelse og svigt af Rusland har været et centralt tema i den offentlige debat i landet og dermed også i befolkningens syn på Vesten. Og fra de inderste politiske kredse er det siden blevet suppleret af en fortælling om et Vesten, som med en aldrig svækket mistro betragter enhver russisk imødekommelse som et forsøg på at vinde tid, inden det næste slag skal slås ( $f x$ Hansen 2002a); et Vesten som ser Rusland som den evigt ekspansionistiske og imperialistiske stat, der ønsker at udbrede sit despotiske styre, hvad enten det er klædt i hvidt, rødt eller hvidt-blåt-rødt, til de omkringliggende områder (Krasheninnikova 2006: 305).

Denne fortælling kommer bl.a. til udtryk i ideen om „det suveræne demokrati“, som Putins ideologiske rådgiver Vladislav Surkov præsenterede i midten af 2000'erne. Surkov har med stor succes formuleret en samlet - og også samlende - ideologi for det nuværende Rusland. Det er en central tanke i ideologien, at de forskellige stater indretter deres respektive politiske styreformer efter de vilkår, som er gældende i de pågældende stater. Menneskets stræben efter frihed (borgerlige rettigheder) og indflydelse (politiske rettigheder) er universel, men vejen dertil er uens; fortiden har efterladt et politisk aftryk, som nogle gange lettere, nogle gange vanskeligere, lader sig slette.

Surkov forklarer videre, at styreformen i den enkelte stat skal afspejle dens aktuelle behov, som igen er et resultat af bl.a. det historiske aftryk. Hvis staten forsømmer at efterleve denne regel, risikerer den at svække sig selv og dermed gøre sig selv til et let bytte for andre stater. Han benytter udtrykket „politisk konkurrencedygtighed“ om dette forhold; på det økonomiske marked overlever den mest konkurrencedygtige aktør, og således er det også på det politiske marked, hvor de stærkere stater står på spring for at udnytte de svagere. Ifølge Surkov gjorde Rusland sig svag i 1990'erne ved at gennemføre forhastede politiske reformer, som bl.a. Vesten insisterede på, var de rigtige for landet. Blandt disse reformer var fejringen af individet snarere end kollektivet og svækkelsen af statens muligheder for at håndhæve love og regler. Resultatet var, dels at Rusland i stort omfang brød sammen, dels at landet blev udnyttet af Vesten, som hurtigt rullede landets indflydelse tilbage, begrænsede dets handlefrihed og reducerede dets kapabiliteter (Surkov 2007; Hansen 2008).

Ideen om det suveræne demokrati er siden blevet antaget som platformen for partiet Det Forenede Rusland (www.edinros.ru), som Putin er formand for. Partiet nyder et absolut flertal i Dumaen, parlamentets underhus, og det suveræne demokrati har på den måde opnået status 
af semiofficiel ideologi i Rusland. På denne baggrund tegner der sig et billede af et Rusland, som i dag i væsentlig grad ser sig selv i kamp med sine omgivelser, som er forberedt på det værste, og som i særdeleshed er mistroisk overfor Vesten.

Det skal tilføjes, at der trods den politiske ensretning i Rusland har været - og stadig er - en række alternativer til denne fortælling. På samme måde som Jeltsin og hans støtter måtte konkurrere mod en bred front af politiske modstandere, som alle mente, at samarbejdet med Vesten førte til et svigt af Ruslands interesser, ja så har der naturligvis heller ikke alene været ensidig opbakning bag Putin og hans folk. Tendensen, således som den fx kan observeres i valgene til Dumaen, viser dog tydeligt, at de provestlige partier har fået det stadig sværere og er blevet stadig mere marginale i russisk politik ( $\mathrm{fx}$ www. russiavotes.org).

Meningsmålinger viser $\mathrm{fx}$ også, at stadig flere russere anbefaler, at man aktivt forsøger at balancere Vesten og dermed begrænser dets indflydelse. I $1998 \mathrm{blev}$ dette synspunkt delt af $35 \%$ af befolkningen, mens $33 \%$ anbefalede et samarbejde med Vesten på baggrund af fælles værdier; i 2008 var disse andele hhv. 44 og $33 \%$, mens $22 \%$ var uafklarede (VTsIOM 2008).

En del af forklaringen på denne udvikling skal utvivlsomt findes i den kritik - nogle vil sige dæmonisering - af Vesten, som bl.a. Putin har stået for. Vi finder et eksempel på dette i hans foreløbigt sidste tale som præsident på Sejrsdagen den 9. maj (Putin 2007b), hvor han forklarede den russiske befolkning, at

„... årsagerne til enhver krig skal først og fremmest findes i de fejltagelser og fejlberegninger, som bliver gjort $\mathrm{i}$ fredstid, årsager som skyldes en konfrontationssøgende og ekstremistisk ideologi. Det er så meget mere vigtigt, at vi husker på dette i dag, da disse trusler ikke bliver færre men blot forandrer sig og skifter udseende. Disse nye trusler viser den samme foragt for menneskeliv og den samme ambition om at kunne diktere sin vilje til resten af verden, som Det Tredje Rige gjorde. Det er min overbevisning, at kun fælles ansvar og ligeværdigt partnerskab kan imødegå disse udfordringer og gøre det muligt for os at modstå forsøg på at starte nye væbnede konflikter og undergrave den globale sikkerhed“.

Tematisk var talen en fortsættelse af Putins kontroversielle indlæg på sikkerhedskonferencen i München i februar 2007, hvor han i hidtil uhørte skarpe vendinger bl.a. advarede mod en fortsat udvidelse af NATO og mod de daværende planer om at opstille et antimissilsystem i Polen og Tjekkiet, ligesom han kritiserede USA’s påstå- ede monopolisering af de internationale forhold (Putin 2007a). Det er, må man forstå, Vesten og især USA, som udgør en trussel mod verdensfreden og derfor også mod Rusland; sidstnævnte er nødt til at tilpasse sin politik til denne virkelighed.

Som allerede nævnt skal vi være opmærksomme på, om vi har bidraget til denne gradvise proces $i$ retning af øget konfrontation ved ikke i tilstrækkelig grad at lade russerne indtage deres nye og, synes de selv, velfortjente rolle som en af „os“. Det skal dog samtidig slås fast, at den politiske ændring ikke alene har været et resultat af uindfriede forventninger, følelser af afvisning og skuffelser. Der har også været en god portion bevidst manipulation udført af forskellige politiske aktører. Fx har den russiske udenrigspolitiske forsker Dmitrij Trenin (2007: 169) beskrevet, hvorledes det russiske forsvar tidligt lagde pres på dele af det politiske system for at få fremmanet en ekstern fjende. Årsagen var de hastigt faldende budgetbevillinger, som truede med at gøre et stort antal officerer arbejdsløse, forringe lønnen for dem, som stadig var i arbejde, forsinke fornyelsen af materiel og generelt gøre det mindre attraktivt og prestigefuldt at tjene i det russiske forsvar. Man havde derfor behov for at vise, at der var alvorlige trusler mod landet. Og som Trenin forklarer (2007: 169), så blev forsvarets ønske til sidst indfriet af velvillige politikere.

Omfattende studier har således vist, hvorledes russiske politikere allerede i begyndelsen af 1990'erne meget effektivt begyndte at overbevise befolkningen om, at de egentlige kilder til Ruslands problemer skulle findes udenfor landets grænser. Oppositionen ønskede at fremstille det som om, Ruslands nye vestlige partnere var både svigagtige og aggressive, og at landets ledelse derfor arbejdede imod de nationale interesser. Snart måtte også Jeltsin og hans skiftende regeringer følge med for at vise, at de skam var kritiske over for Vesten, ligesom de også hurtigt så en interesse i at aflede vælgernes opmærksomhed fra de mange hjemlige problemer.

Man skabte på denne måde en fortælling om et Vesten, som ønsker at isolere og omringe Rusland og, ved at bremse dets økonomiske vækst, forhindre det i at følge sin egen politiske kurs. I dette ser vi kimen til den proces, som foreløbigt er kulmineret med Surkovs formulering af ideen om den politiske konkurrencedygtighed. Og på denne baggrund havde de russiske politikere held til at få vælgerne til at bekymre sig meget mere om Vesten, og i særdeleshed USA og NATO, end alt tyder på, de ellers ville have gjort (Zimmermann 2002).

Som allerede nævnt lå de antivestlige følelser latent lige under overfladen på dette tidspunkt. For en del af den russiske befolkning var der således blot tale om, at deres politiske præferencer (igen) fandt repræsentation i 
det politiske system, og at de nu mere legitimt kunne give udtryk for deres modstand mod Vesten. Men der var tillige en ganske omfattende proces af såkaldt eksogen præferenceformation, hvor politikerne formåede at få de russiske vælgere til at forfølge præferencer, som før var perifære i forhold til andre præferencer eller måske endog helt ikkeeksisterende. Politikerne havde m.a.o. held til at overdrage nye værdier og mål til vælgerne - i dette tilfælde at se Vesten som en konkurrent og som en del af „dem“ og dermed også at få opprioriteret en mere selvstændig og ikkevestlig udvikling for Rusland (fx Kozhemiakin 1997).

Sådanne processer er velbeskrevet i demokratiseringsteorier (fx Snyder 2000), hvor de er anført som nogle af faldgruberne. Rusland har været et skoleeksempel på, hvorledes mere eller mindre skrupelløse politikere har kunnet skabe en ny og anderledes virkelighed, som siden er blevet antaget som den „korrekte“ fortolkning af udviklingen og af forholdene. Processen har ført til et mere udtalt skel mellem „os“ og „dem“, dvs. mellem Rusland og Vesten, men de russiske politikere vil naturligvis anføre, at det var Vesten, som i første omgang insisterede på at bevare et dikotomiseret forhold.

I Rusland er politikernes arbejde med at skabe et øget modsætningsforhold til Vesten blevet lettet af en forholdvis svag politisk kultur, som søger nemme „sorthvide" svar på ellers komplicerede spørgsmål, såvel som af de politisk kontrollerede og ukritiske medier. Studier ( $f x$ Snyder 2000) indikerer, at stater, som befinder sig mellem autokrati og demokrati har en større risiko for at blive inddraget i væbnet konflikt end stater, som er tættere på de to nævnte ekstremer. Det skyldes en kombination af to forhold. For det første, at stater som gennemgår demokratisering ofte har en meget vidtrækkende politisk debat, hvor politikerne forsøger at overbyde hinanden for at vinde vælgernes gunst (hvilket ikke sker i autokratiet). Og for det andet at de endnu ikke har fået skabt frie og kritiske medier, som kan dissikere politikernes overbudspolitik og vise, at „de“ ikke er årsag til alle „vores“ problemer, og at dæmoniseringen af „dem“ blot er et forholdsvis simpelt politisk trick (som det sker i demokratiet). I det russiske tilfælde har den primære indre „de“ været tjetjenerne, mens den vigtigste eksterne „de“ har været Vesten generelt og USA og NATO mere specifikt.

Den russiske befolkning ser utvivlsomt det uheldige i hele denne udvikling. Alligevel har den altså siden midten af 1990'erne taget en række skridt, som gør, at Rusland og Vesten er vendt tilbage til et materielt opslidende eller ligefrem destruktivt forhold, hvor de to parter i høj grad retter kræfterne mod hinanden. Det kan virke paradoksalt, men det er en udvikling, som er velkendt for sikkerhedsteorien - og for psykologien ikke mindst. Sikkerhedsteoretikeren Jennifer Mitzen (2006: 347) sammenligner således situationen med den, som $\mathrm{fx}_{\mathrm{x}}$ voldsramte kvinder kan befinde sig i. Den enkelte kvinde vælger måske at blive i forholdet, fordi hun har svært ved at se sig selv som et selvstændigt individ med egen identitet uden for forholdets velkendte og veldefinerende rutiner, rammer og roller. Forholdet er ikke godt for hende, og det erkender hun, men via det får hun sin identitet, og det giver hende omgivelser, som hun er fortrolig med. Alternativet kan være alt for usikkert og byde på for mange udfordringer, fordi rollerne er ukendte.

Som allerede antydet er mistroen til Vesten, for nu at sætte det lidt på spidsen, den russiske default. Det er en overbevisning, de ikke skal anstrenge sig for at nå. For mange russere faldt brikkerne derfor på plads igen, da de af deres politikere blev forklaret, at Vesten i virkeligheden slet ikke ønsker, at Rusland skal komme sig efter Sovjetunionens sammenbrud. For dem er forholdet mellem de to parter en lang fortælling om Vestens frygt for og afvisning af den russiske kæmpe. De ser dette mønster gentaget nu, og de er overbeviste om, at Rusland er nødt til at hjælpe sig selv, og at genrejsningen vil ske på trods af Vesten.

\section{At tilfredsstille en ontologisk sikkerhedssøger}

Den primære pointe i dette er, at hele den skitserede udvikling har skadet forholdet mellem Rusland og Vesten, men også at den har givet den russiske befolkning en stærkere følelse af ontologisk sikkerhed. En større del af befolkningen kan nu langt klarere end for 10-15 år siden besvare de ovennævnte spørgsmål som: Hvilken type af stat er Rusland egentlig? Hvad er landets identitet? Og hvad er Ruslands interesser? Desværre vil svarene i stor udstrækning hvile på modstand mod Vesten.

En artikel om konstruktionen af fjendebilleder i Rusland opsummerede det uheldige paradoks meget rammende med den fantastiske - og fantastisk eksistentialistiske - titel „Ich hasse, also bin ich“ (Gudkov 2002). Udfordringen er at få den brede russiske befolkning til at føle sig sikker i en identitet, som er baseret på andre og mere positive værdier og normer end de nuværende. Det er tydeligvis ikke nogen let opgave, og problemet vil kun blive løst meget gradvis.

Teoretikere taler nogle gange om en fælles skæbne ( $\mathrm{fx}$ Wendt 1999: 349-353), som kan få stridende aktører til at fokusere mindre på det skarpt adskillende „dem“ og mere på det samlende „os“. Den fælles skæbne kan fx være en tredje aktør, som ikke er del af den indbyrdes konflikt, men hvis handlinger får de oplevede forskelle mellem „os" og „dem“ til at synes ubetydelige. Umiddelbart ef- 
ter angrebet på USA den 11. september 2001 talte man om Al-Qaeda som en mulig fælles konstituerende anden, dvs. som en aktør, som både Rusland og Vesten kunne definere sig i modsætning til. Nu er det dog tydeligt, at truslen fra den internationale terrorisme ikke har været stærk nok til rigtig at bringe Rusland og Vesten tættere på hinanden.

Uden en pludselig fælles skæbne til at redefinere forholdet må vi i stedet anvende tillidsskabende foranstaltninger. Ansvaret hviler på både Rusland og Vesten, for det sociale rum mellem forskellige aktører kan alene omformes, hvis alle involverede parter deltager (Mitzen 2006: 363). De velkendte og negative rutiner skal brydes og erstattes af nye og positive rutiner, hvor tillidsforholdet bliver bekræftet og derved gradvis styrket. Det er processer, som med stort held er gennemført i forhold til fx en lang række af landene i den tidligere Østblok. De var jo alle en del af „dem“, men via deres egen åbenhed og vores bekræftende imødekommenhed blev de gradvis fuldgyldige medlemmer af „vores“ fællesskab.

Det første skridt vil dog føre til en umiddelbar svækkelse af aktørens ontologiske sikkerhed, for det betyder, at denne må forlade det velkendte (Mitzen 2006: 362). I den konkrete problemstilling er det derfor nok mest realistisk, at Vesten tager det primære initiativ. Det er vigtigt for mig at understrege, at dette ikke på nogen måde indikerer, at vi dermed også påtager os den primære skyld. I stedet er årsagen simpelthen, at vi ontologisk er mest sikre. Sagt på en anden måde „hviler" vi mere i vores identitet, har et stærkere selv, og er derfor også mindre fokuserede på at (re)definere vores identitet via forholdet til Rusland. For den russiske side berører forholdet derimod noget mere centralt: Det er en større del af deres væren, som bliver bragt i spil, når de interagerer med os.

Vestens mål skal være at svække den simple og populære russiske fortælling om, at vi vil dem ondt. Dermed kan vi gøre os håb om at levere et alternativ til den antivestlige identitet, som er skabt i landet, og ultimativt kan vi håbe på, at de vil føle sig sikre i en identitet, som ikke er defineret ved dens påståede forskelle fra vores. Som et første skridt bør vi glide af på nogle af de internationale konfrontationer, som førende russiske politikere iscenesætter, fordi det tjener deres interesser. Det betyder slet ikke, at vi skal slække på vores krav og forventninger til Rusland. Men vi bør vælge konfrontationerne med omhu og sikre os, at vi ikke faktisk støtter de antivestlige politikere ved at spille deres spil.

Det skal således erindres, at ledende meningsdannere i Rusland i dag benytter fortællingen om Vesten instrumentelt; de har simpelthen gavn af at overbevise vælgerne om, at Vesten ønsker at se Rusland i knæ. Vi kan undgå dette ved mere eller mindre at ignorere de mest symbolske provokationer. Deres vigtigste formål er at få os til at reagere på en måde, som synes at vise, at den påståede mistillid til Rusland er intakt. Og efterfølgende bruges de til at cementere Ruslands identitet som modstillet Vesten.

Hvis opgangens nye og fremmede beboer viser sig at være en hærdet voldsforbryder, som gang på gang truer sine naboer med tæv, ja så kan det i sidste ende måske vise sig umuligt at nå ind til vedkommende med tillidsskabende foranstaltninger. Det kan også vise sig at være tilfældet med Rusland, som jo flere gange har truet Vesten og opført sig særdeles hårdhændet over for sine naboer i SNG.

Men indtil vi har nået dette punkt, kan det fx overvejes, hvorledes Vesten i højere grad kan lade Rusland indtage symbolske roller i det fælles forhold; roller som vil vise, at vores afstand til dem ikke er så stor som deres afstand til os, og at vi derfor tør bryde med de velkendte roller. På det mere praktiske plan kan vi fx invitere til et tættere økonomisk og militært samarbejde, til øget udveksling af både militære og civile studerende og til fælles forskningsmæssige og kulturelle aktiviteter.

På samme måde som begge parter skal bestræbe sig på at være deres kognitive begrænsninger bevidste, så skal der afslutningsvis opfordres til, at de også i det stille forsøger at efterleve Rogers' råd (2004: 332) til sine samspilsramte klienter:

„The next time you get into an argument with your wife, or your friend, or with a small group of friends, just stop the discussion for a moment and for an experiment, institute this rule: 'Each person can speak up for himself only after he has first restated the ideas and feelings of the previous speaker accurately, and to that speaker's satisfaction'... It would simply mean that before presenting your own point of view, it would be necessary for you to really achieve the other speaker's frame of reference...".

Det kan naturligvis ikke efterleves i praksis, men det kunne sikkert gøre underværker for den gensidige forståelse, hvis russiske og vestlige aktører via offentlige kommunikative handlinger forsøgte at forklare og forsvare den anden parts politik. Det kunne øge forstålsen af omstridte handlinger som fx NATO-udvidelse og stop for russiske energileverancer til nabolandene i SNG. Måske kan vi så få overbevist begge parter om, at „de“ egentlig ikke er så meget anderledes end „os“. 


\section{Referencer:}

Basjanov, Je 2001, Aktualnye problemy mesjdunarodnykh otnosjenij, Moskva: Nautjnaja kniga, vol. I

Bird, A 2002, Philosophy of Science, Milton Park: Routledge

Dobriansky, P 2000, „Russian Foreign Policy: Promise or Peril?", The Washington Quarterly, vol. 23, nr. 1, pp. 135-144

Giddens, A 1991, Modernity and Self-Identity: Self and Society in the Late Modern Age, Stanford, CA: Stanford University Press

Goffman, E 1958, The Presentation of Self in Everyday Life, Edinburgh: University of Edinburgh Press

Gudkov, L 2002, „Ich hasse, also bin ich - Zur Funktion der AmerikaBilder und die Anti-Amerikanismus in Russland“, Osteuropa, vol. 52, nr. 8, pp. 997-1014

Hansen, F 2002a, „Past and Future Meet: Aleksandr Gorchakov and Russian Foreign Policy“, Europe-Asia Studies, vol. 54, nr. 3, pp. 377-396

Hansen, F 2002b, „Explaining Russian Endorsement of the CFSP and the ESDP“, Security Dialogue, vol. 33, nr. 4, pp. 443-456

Hansen, F 2008, „Den moderne russiske stat“, Militert Tidsskrift, vol. 137. nr. 3, pp. 280-294

Heuer, R 1999, Psychology of Intelligence Analysis, Washington, DC: Central Intelligence Agency

Ichheiser, G 1949, „The Image of the Other Man“, The American Journal of Sociology, vol. 55, nr. 2, pp. 5-11

Jervis, R 1976, Perception and Misperception in International Politics, Princeton, NJ: Princeton University Press

Kozhemiakin, A 1997, „Democratization and foreign policy change: the case of the Russian Federation", Review of International Studies, vol. 23, nr. 1, pp. 49-74

Krasheninnikova, V 2007, Amerika-Rossija: Kholodnaja voina kultur, Moskva: Evropa

Laing, R 2006 [1964], The Divided Self-An Existential Study in Sanity and Madness, Milton Park: Routledge

Lusjkov, J 2007, „My i zapad“, i Poljakov, L, Pro suverennuju demokratiju, Moskva: Evropa, pp. 195-207

McSweeney, B 1999, Security, Identity and Interests: A Sociology of International Relations, Cambridge: Cambridge University Press

Mitzen, J 2006, „Ontological Security in World Politics: State Identity and the Security Dilemma“, European Journal of International Relations, vol. 12, nr. 3, pp. 341-370
Putin, V 2007a, Speech at the $43^{\text {rd }}$ Munich Conference on Security Policy, den 10. februar; I http:www.securitconference.de

Putin, V 2007b, Speech at the Military Parade Celebrating the $62^{\text {nd }}$ Anniversary of Victory in the Great Patriotic War, den 9. maj; i http:// eng.kremlin.ru

Razuvajev, V 1992, „Forecast: Sticks and Carrots - Controversial Reflections on Russian Foreign Policy“, Nezavisimaja gazeta, 5. marts; i The Current Digest of the Post-Soviet Press, vol. 44, nr. 10, p. 15

Rogers, C 2004 [1967], On Becoming a Person, London: Constable Snyder, J 2000, From Voting to Violence, New York, NY: W W Norton Southgate, B 1996, History: What and Why, London: Routledge

Steele, B 2005, „Ontological security and the power of self-identity: British neutrality and the American Civil War", Review of International Studies, vol. 31, pp. 519-540

Steele, B 2008, Ontological security in international relations: self-identity and the IR state, Milton Park: Routledge

Surkov, V 2007, „Suverenitet - eto polititjeskij sinonim konkurentosposobnosti“, i Poljakov, L, Pro suverennuju demokratiju, Moskva: Evropa, pp. 33-61

Taylor, C 2006 [1989], Sources of the self: The making of modern identity, Cambridge: Cambridge University Press

Trenin, D 2007, „The Role of Russian Power Structures in Domestic Politics and Foreign Policy: What the Future Holds", I Leijonhielh, J og Westerlund, F, red., Russian Power Structures - Present and Future Roles in Russian Politics, Stockholm: Totalförsvarets Forskninginstitut, pp. 165-179

Tsygankov, A 2004, Whose World Order? Russia's Perception of American Ideas after the Cold War, Notre Dame, IN: University of Notre Dame Press

Tsygankov, A 2006, Russia's Foreign Policy: Change and Continuity in National Identity, Lanham, MD: Rowman \& Littlefield

Vserossijskij Tsentr Izutjenija Obshestvennogo Mnenija [VTsIOM] 2008, Rossija i Zapad posle "prinusjdenija $k$ miru": Partnerstvo ili vrasjda?, den 4. september; i www.wciom.ru

Wendt, A 1999, Social Theory of International Politics, Cambridge: Cambridge University Press

Zimmerman, W 2002, The Russian People and Foreign Policy: Russian Elite and Mass Perspectives, 1993-2000, Princeton, NJ: Princeton University Press 